\title{
Amaranthus genetic resources in Indonesia: morphological and protein content assessment in comparison with worldwide amaranths
}

\author{
Rita Andini · Shigeki Yoshida $\cdot$ Yasuko Yoshida • \\ Ryo Ohsawa
}

Received: 10 May 2012/ Accepted: 18 February 2013/Published online: 27 March 2013

(C) The Author(s) 2013. This article is published with open access at Springerlink.com

\begin{abstract}
The morphological variations (growth habit, leaf shape, leaf color, height, stem diameter, number of branches and internodes, leaf area, blade ratio, leaf thickness, number of leaves, and total leaf area) and protein content of 53 Indonesian amaranths (Amaranthus spp.), consisting of weedy-, vegetable-, and ornamental-types, were assessed. The extent of variation in the Indonesian Amaranthus accessions were compared with the worldwide collection (26 accessions from United States Department of Agriculture (USDA) and 5 ornamentals from Nepal) in the experimental field of the University of Tsukuba, Japan. The variation in average values of most morphological traits and protein content in the Indonesian accessions were similar to those of the worldwide germplasm, but the important parameters that influence vegetable yield (e.g., number of leaves and stem diameter) were superior in the Indonesian accessions. Protein content showed a positive correlation with the number of leaves, whereas a negative correlation was observed with leaf thickness. The Indonesian accession of $A$. viridis and A. dubius showed a great potential to be further selected as parental lines for high protein content and number of leaves. The relatively high protein content of the
\end{abstract}

R. Andini · S. Yoshida · Y. Yoshida · R. Ohsawa ( $\square)$ Graduate School of Life and Environmental Sciences, University of Tsukuba, 1-1-1 Tennodai, Tsukuba, Ibaraki 305-8572, Japan

e-mail: osawa.ryo.gt@u.tsukuba.ac.jp leaves of Celosia may also potentially serve as an alternative protein source in the tropics.

Keywords Amaranthus $\cdot$ Celosia $\cdot$ Morphological diversity $\cdot$ Vegetable

\section{Introduction}

The genus Amaranthus consists of up to 70 species (in the form of cosmopolitan weed or cultivated plant) and are widely spread in all tropical and subtropical regions of the world (Espitia-Rangel 1994). They are usually distinguished as grain, vegetable, ornamental, or weedy (i.e., uncultivated) (Brenner et al. 2000). The grain and the vegetable types, whose grain and leaves are highly appreciated for human consumption, are the two major cultivated amaranths. At the same time, the uncultivated amaranths are all weedy, including those that have not yet been cultivated or may escape out of cultivation (Pal 1972). The vivid color of the inflorescence of amaranths makes them attractive enough to be used as ornamental plants.

The utilization of Amaranthus as grain, vegetable or weedy depends on the regional preferences, as some grain species (A. hypochondriacus L., A. caudatus L., and $A$. cruentus L.) may also be utilized as vegetables in Asian and African countries (Hauptli and Jain 1983). A. blitum L. and A. dubius Mart. ex Thell. (also referred to as A. dubius) are associated with weedy 
species. Nevertheless, they are also valued as vegetables in most Asian and African countries (Costea et al. 2003; Grubben 2004). The prominent vegetable species is A. tricolor L., whose leaves are served as an affordable protein source in South-East Asia (Grubben 1994). The young leaves of the ornamental amaranths Celosia spp., which still belong to the family Amaranthaceae (Grubben 1976) are highly appreciated for human consumption in many African countries (Denton 2004; Olaniyi and Ojetayo 2012).

Vegetable amaranths are very popular in Indonesia (Grubben 1994). They are frequently traded in Indonesian traditional markets and are ranked as the third most-consumed leafy vegetables after 'kangkong' (Ipomoea aquatica Forsskal; further referred as 'kangkong') and cassava leaves (Manihot esculenta) (Maulana and Sayaka 2007). They are commonly sold in bundles of 10-20 plants and can be harvested within 3 weeks, with a yield ranging from 2 to 5 tonnes $\mathrm{ha}^{-1}$ per harvest season (Hadisoeganda 1996). Approximately 65,723 and 152,334 tonnes of amaranths were produced in 2000 and 2010, respectively (Indonesian Central Statistic Bureau, cited in December 2011 at http://www.bps.go.id). Amaranths are considered as economically important in Indonesia, as they allow rapid income generation and support small farmers' livelihood.

Despite their popularity in Indonesia, there has been no efforts to improve the nutritional value and productivity of $A$. tricolor $\mathrm{L}$. as the major cultivated vegetable species. Its average protein content in general is approximately $12 \%$ (Shukla et al. 2010). Moreover, the yield noted with leaf production per plant is quite low when compared with other vegetables available in Indonesia; such as cassava and "kangkong" leaves (Wargiono et al. 2002; Westphal 1994). Indonesia is recognized as a biodiversity hotspot in the tropics, and many varieties of amaranths (e.g., vegetable, weedy, and ornamentals) exist. Thus, weedy amaranths bear great potential as good resources for nutritional enhancement as some A. blitum L. was reported to have as much as $38 \%$ protein (Grubben 2004). Moreover, many weedy types showed a great deal of variation with favorable crop morphology (high leaf number, many branches). In the remote highland areas of Takengon in Sumatra, local people have utilized some weedy types closely resemble with the vegetable amaranths as famine food, while the other types have been used as traditional medicine (personal communication). Thus, taking into account the gaps in knowledge of the extent of the Indonesian resources, a thorough assessment of these with the rest of the accessions with regard to nutritional and agronomic features is urgently required.

Research on the extent of the diversity of amaranths would enable us to choose some of the weedy types as prospective genetic resources for useful traits. At the molecular level, Chan and Sun (1997) had assessed the diversity of 23 cultivated species and their relationship with wild Amaranthus by using isozyme and RAPD markers and they found that wild or weedy amaranths were found to be highly polymorphic. Coons (1982) tried to evaluate the yield related traits in grain amaranths (A. caudatus and A. hybridus) such as the flower's component, seed diameters and color. She found that $A$. hybridus showed larger variability in these characters than A. caudatus. Other Asian researchers had tried to evaluate the field performance of Amaranthus in China and the diversity of vegetable amaranths, particularly A. tricolor L. (Wu et al. 2000; Shukla et al. 2010). However, information on the diversity of Indonesian amaranths and the potential of the weedy-types in breeding program has not been reported.

Thus, the aims of this study are to: (1) assess the variations in morphology and protein content of Indonesian amaranths and compare them with the worldwide variation; (2) evaluate the relative potential of Indonesian amaranths for vegetable improvement. These findings are expected to be a valuable contribution to amaranth breeding efforts in Indonesia.

\section{Materials and methods}

Plant materials

In this study, a total of 84 amaranth accessions consisting of grain-, ornamental-, vegetable-, and weedy-types were assessed (Table 1), of which 53 were collected from Sumatra and Java islands of Indonesia in 2008 and 2010 (Fig. 1). The Indonesian collection consisted of 2 accessions of A. blitum L., 2 accessions of A. caudatus L., 16 accessions of A. dubius, 3 accessions of $A$. hybridus, 5 accessions of A. spinosus, 20 accessions of A. tricolor L., 1 accession of $A$. viridis, and 4 accessions of Celosia spp. Seeds were collected from various sites such as 
Table 1 List of plant materials

\begin{tabular}{|c|c|c|c|c|c|c|c|}
\hline $\begin{array}{l}\text { Accession } \\
\text { number }\end{array}$ & Accession name & Type & Species & $\begin{array}{l}\text { Accession } \\
\text { number }\end{array}$ & Accession name & Type & Species \\
\hline & Worldwide & & & 42 & IDN 10/P.One-one & WD & A. spinosus \\
\hline 1 & Ames 5315/IND & VG & A. blitum L. & 43 & IDN 11/Tn.Depet & WD & A. spinosus \\
\hline 2 & PI 610262/IND & VG & A. blitum L. & 44 & IDN 13/Mandua & WD & A. dubius \\
\hline 3 & PI 490298/KEN & VG & A. blitum $\mathrm{L}$. & 45 & IDN 14/Mandua & WD & A. dubius \\
\hline 4 & PI 606281/BGD & VG & A. blitum $\mathrm{L}$. & 46 & IDN 15/Mandua & WD & A. dubius \\
\hline 5 & PI 606282/BGD & VG & A. blitum $\mathrm{L}$. & 47 & IDN 17/Medan & WD & A. dubius \\
\hline 6 & PI 482049/ZWE & GR & A. cruentus $\mathrm{L}$. & 48 & IDN 18/Medan & WD & A. blitum $\mathrm{L}$. \\
\hline 7 & PI 482051/ZWE & GR & A. cruentus L. & 49 & IDN 19/Mandua & WD & A. blitum $\mathrm{L}$. \\
\hline 8 & PI 490662/BEN & GR & A. cruentus $\mathrm{L}$. & 50 & IDN 20/Ygy & WD & A. dubius \\
\hline 9 & PI 494777/ZMB & GR & A. cruentus L. & 51 & IDN 22/Ygy & WD & A. dubius \\
\hline 10 & PI 500267/ZMB & GR & A. cruentus $\mathrm{L}$. & 52 & IDN 23/Ygy & WD & A. dubius \\
\hline 11 & PI 538319/USA & GR & A. cruentus $\mathrm{L}$. & 53 & IDN 24/JKT & WD & A. dubius \\
\hline 12 & PI 566897/IND & GR & A. cruentus $\mathrm{L}$. & 54 & IDN $25 / \mathrm{JKT}$ & WD & A. dubius \\
\hline 13 & PI 604666/USA & GR & A. cruentus $\mathrm{L}$. & 55 & IDN 26/JKT & WD & A. dubius \\
\hline 14 & PI 605352/JAM & VG & A. dubius & 56 & IDN 27/JKT & WD & A. dubius \\
\hline 15 & PI 642737/PRI & VG & A. dubius & 57 & IDN 29/K.Urang & VG & A. tricolor $\mathrm{L}$. \\
\hline 16 & PI 608661/IND & VG & A. graecizans & 58 & IDN 30/K.Urang & VG & A. tricolor $\mathrm{L}$. \\
\hline 17 & PI 500249/ZMB & GR & A. hybridus & 59 & IDN 33/Lembang & VG & A. caudatus $\mathrm{L}$. \\
\hline 18 & PI 605351/GRC & GR & A. hybridus & 60 & IDN 34/Lembang & VG & A. caudatus $\mathrm{L}$. \\
\hline 19 & PI 604577/MEX & GR & A. hypochondriacus L. & 61 & IDN 35/BNA & VG & A. tricolor $\mathrm{L}$. \\
\hline 20 & Ames 5134/USA & VG & A. tricolor $\mathrm{L}$. & 62 & IDN 36/BNA & VG & A. tricolor $\mathrm{L}$. \\
\hline 21 & PI 349553/PNG & VG & A. tricolor $\mathrm{L}$. & 63 & IDN 37/BNA & VG & A. tricolor $\mathrm{L}$. \\
\hline 22 & PI 566899/IND & VG & A. tricolor $\mathrm{L}$. & 64 & IDN 38/BNA & VG & A. tricolor $\mathrm{L}$. \\
\hline 23 & PI 604669/TWN & VG & A. tricolor $\mathrm{L}$. & 65 & IDN 39/BNA & OR & Celosia spp. \\
\hline 24 & PI 586680/USA & OR & C. argentea & 66 & IDN 40/BNA & VG & A. tricolor $\mathrm{L}$. \\
\hline 25 & PI 482244/ZWE & OR & C. trigyna & 67 & IDN 41/Marelan & VG & A. tricolor $\mathrm{L}$. \\
\hline 26 & PI 608761/IND & VG & A. tricolor $\mathrm{L}$. & 68 & IDN 42/Marelan & VG & A. tricolor $\mathrm{L}$. \\
\hline 27 & NPL 01/KTM & OR & Celosia spp. & 69 & IDN 43/Marelan & VG & A. tricolor $\mathrm{L}$. \\
\hline 28 & NPL 02/KTM & OR & Celosia spp. & 70 & IDN 44/Marelan & VG & A. tricolor $\mathrm{L}$. \\
\hline 29 & NPL 03/KTM & OR & Celosia spp. & 71 & IDN 45/Marelan & VG & A. tricolor $\mathrm{L}$. \\
\hline 30 & NPL 04/KTM & OR & Celosia spp. & 72 & IDN 46/Kresek & VG & A.tricolor L. \\
\hline \multirow[t]{2}{*}{31} & NPL 05/KTM & OR & Celosia spp. & 73 & IDN 47/Kresek & VG & A. tricolor $\mathrm{L}$. \\
\hline & Indonesia & & & 74 & IDN 48/Kresek & VG & A. tricolor $\mathrm{L}$. \\
\hline 32 & PI 540445/IDN/Java & WD & A. viridis & 75 & IDN 49/Yates & OR & Celosia spp. \\
\hline 33 & IDN 01/Mongal & WD & A. dubius & 76 & IDN 50/P. Merah & VG & A. tricolor $\mathrm{L}$. \\
\hline 34 & IDN 02/Daling & WD & A. dubius & 77 & IDN 51/P. Merah & VG & A. tricolor $\mathrm{L}$. \\
\hline 35 & IDN 03/Daling & WD & A. dubius & 78 & IDN 52/SHS & VG & A. tricolor $\mathrm{L}$. \\
\hline 36 & IDN 04/Bur biah & WD & A. spinosus & 79 & IDN 53/SHS & VG & A. tricolor $\mathrm{L}$. \\
\hline 37 & IDN 05/Bur biah & OR & Celosia spp. & 80 & IDN 54/Tanindo & VG & A. tricolor $\mathrm{L}$. \\
\hline 38 & IDN 06/Bur biah & OR & Celosia spp. & 81 & IDN 55/P.Kb & WD & A. hybridus \\
\hline 39 & IDN 07/Ulu Nuih & WD & A. spinosus & 82 & IDN 56/P.Kb & WD & A. spinosus \\
\hline 40 & IDN 08/Asir-asir & WD & A. dubius & 83 & IDN 57G/P.Kb & WD & A. hybridus \\
\hline 41 & IDN 09/Asir-asir & WD & A. dubius & 84 & IDN 57R/P.Kb & WD & A. hybridus \\
\hline
\end{tabular}

$G R$ grain, $O R$ ornamental, $V G$ vegetable, $W D$ weedy-type of amaranth

Country code: $B E N$ Benin, $B G D$ Bangladesh, GRC Greece, IDN Indonesia, IND India, JAM Jamaica, KEN Kenya, MEX Mexico, NPL Nepal, PNG Papua New Guinea, PRI Puerto Rico, TWN Taiwan, USA United States of America, ZMB Zambia, ZWE Zimbabwe. City code: BNA Banda Aceh, JKT Jakarta, KTM Kathmandu, P.Kb Payakumbuh, Ygy Yogyakarta. Seed producer code: P.Merah Panah Merah, SHS Sang Hyang Sri 
Fig. 1 Map of the sample collection regions (blue dots) for Indonesian amaranths

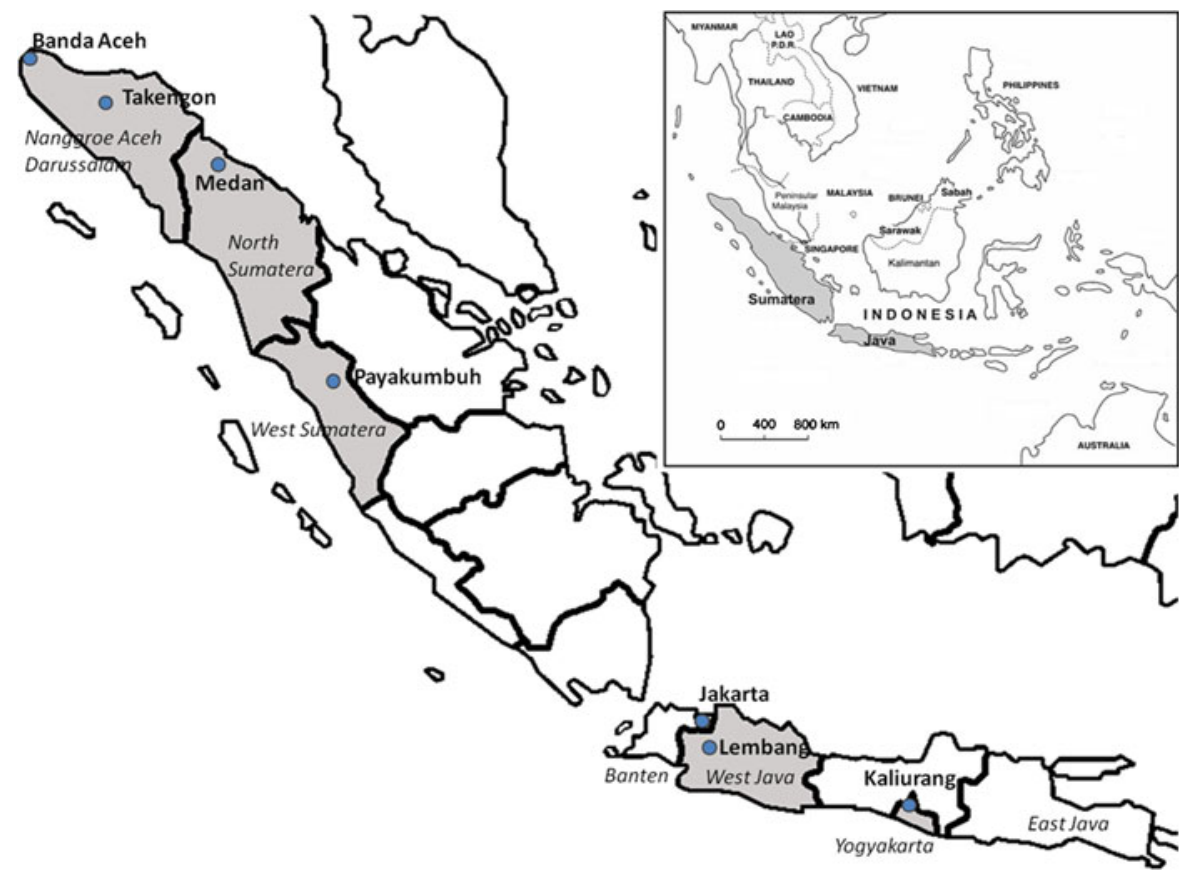

Experimental site

farmers' fields located in the villages and urban areas, home yards, and disturbed habitats such as roadsides, open or abandoned places, riverbanks, lake sides, and communal forests at the mountainous areas, with the elevation ranging from 100 to $1,200 \mathrm{~m}$ above sealevel.

A total of 31 worldwide accessions consisting of grain-, vegetable-, and ornamental-types were also assessed in this study. Seeds from 13 diverse origins (Africa, America, and Asia) representing the worldwide variation was provided by the United States Department of Agriculture-Agricultural Research Service (USDA-ARS), North Central Regional Plant Introduction Station (NCRPIS) in Ames (Iowa, USA). These consisted of 5 accessions of A. blitum L., 8 accessions of A. cruentus L., 2 accessions of A. dubius, 1 accession of $A$. graecizans, 2 accessions of $A$. hybridus, 1 accession of $A$. hypochondriacus L., 5 accessions of $A$. tricolor L., and 2 accessions of Celosia. In addition, 5 accessions of Celosia spp. were purchased in 2010 by one of the author in Kathmandu (Nepal). Species of the USDA accessions were identified by USDA personnel and available online (USDA 2011). The Indonesian materials were classified on the basis of their utilization (e.g., weedy-, vegetable, or ornamental-types), as described by local farmers and according to amaranth's descriptors (Brenner 2002; Grubben 1976).
The experiment was conducted in vinyl houses located at the experimental field of the Agriculture and Forestry Research Centre, University of Tsukuba (Ibaraki, Japan), which is situated approximately $28 \mathrm{~m}$ above sea-level $\left(36^{\circ} 07^{\prime} 01.71^{\prime \prime}\right.$ latitude and $140^{\circ} 05^{\prime} 40.24^{\prime \prime}$ longitude) with a mean temperature of $20{ }^{\circ} \mathrm{C}$ during the growing season. Seeds from the 84 accessions were germinated on 6 August 2010 in plastic trays $(6 \times 6$ holes; diameter, $4 \mathrm{~cm}$; depth, $4.7 \mathrm{~cm}$ ) containing a growing medium without fertilizer ("Metromix" from Sungro). Three weeks after sowing, 3 or 4 plants per accession were selected and transplanted into clay pots (diameter, $18 \mathrm{~cm}$; height, $16.5 \mathrm{~cm})$ with ready soil "Sumirin" $\left(\mathrm{N}: \mathrm{P}_{2} 0_{5}: \mathrm{K}_{2} \mathrm{O}=\right.$ $120: 1,000: 50 \mathrm{mg} / \mathrm{l}, \mathrm{pH}=6.7)$. From each pot that contained 3 or 4 plants, only 1 plant was selected for the trait measurement. Five pots were prepared for each accession. The pots were arranged according to a completely randomized experimental design.

Morphological traits

Measurements of morphological traits according to guidelines provided in Amaranthus' descriptor (Brenner 2002) and Grubben (1976); were taken before flowering 2-3 months after sowing. The twelve 
morphological traits included qualitative, plant architecture, leaf character, and vegetable production (Table 2). All quantitative traits presented were mean values of measurements on five plants. Data on quantitative and qualitative characteristics were compared between the Indonesian and worldwide accession on histrogram.

Stem diameter and leaf thickness were measured with a slide caliper (Digimatic Solar DC-S15 m, Mitutoyo, Japan). Leaf area was measured by using VH-analyzer image analyses software (version 2.20, Keyence Co., Ltd., Osaka, Japan). Before measurement, the leaves were arranged on a white paper background and scanned on a GT-9800 F scanner (EPSON, Tokyo, Japan), with a $1-\mathrm{cm}^{2}$ color marker as the standard. Three different representative leaf sizes (small, middle, and large) per plant were randomly sampled for measurement of leaf thickness and area.
The values for leaf thickness and area represented average values of 15 measurements ( 5 plants per accession for each of the 3 different leaf sizes). Some weedy types had many very small leaves along the branches therefore, countable leaves were counted as number of leaves per plant. Total leaf area was calculated by multiplying the number of leaves per plant with the average leaf area. This was applied as an indirect measure of productivity in amaranths.

\section{Protein analysis}

Crude protein content was determined by the Kjeldahl method; protein content was determined as percentage of dry weight by multiplying the nitrogen content $(\mathrm{N})$ by the conversion factor of $6.25(\mathrm{~N} \times 6.25)$ (AOAC 1980). Fresh leaves (10-25 g) were cut from 2 to 3-month-old plants. Leaves were ground in liquid

Table 2 List of morphological traits analyzed

\begin{tabular}{|c|c|c|c|}
\hline Number & Morphological trait & Method & Data-type \\
\hline & \multicolumn{3}{|l|}{ Qualitative traits } \\
\hline 1. & Growth habit ${ }^{\mathrm{a}}$ & Visual observation & Category \\
\hline 2. & Leaf shape ${ }^{b}$ & Visual observation & Category \\
\hline \multirow[t]{2}{*}{3.} & Leaf color ${ }^{\mathrm{c}}$ & Visual observation & Category \\
\hline & \multicolumn{3}{|l|}{ Plant architecture traits } \\
\hline 4. & Plant height $(\mathrm{cm})$ & $\begin{array}{l}\text { Measurement of the height of a plant from the } \\
\text { soil surface to the top of the inflorescence }\end{array}$ & Numerical \\
\hline 5. & Stem diameter $(\mathrm{mm})$ & Measurement of the diameter of the middle part of the main stem & \\
\hline 6. & $\begin{array}{l}\text { Number of branches on the } \\
\text { main stem (no.) }\end{array}$ & $\begin{array}{l}\text { Number of branches were counted along the main stem } \\
\text { at the maturity growth stage }\end{array}$ & Numerical \\
\hline \multirow[t]{2}{*}{7.} & $\begin{array}{l}\text { Number of internodes on the } \\
\text { main stem (no.) }\end{array}$ & $\begin{array}{l}\text { Number of internodes were counted along the main } \\
\text { stem at the maturity growth stage }\end{array}$ & Numerical \\
\hline & \multicolumn{3}{|l|}{ Leaf character traits } \\
\hline 8. & Leaf area $\left(\mathrm{cm}^{2}\right)$ & Measurement of the area of one leaf using VH-analyzer software & Numerical \\
\hline 9. & Blade ratio (length:width) & Measurement of the length and width of a blade & Numerical \\
\hline \multirow[t]{2}{*}{10.} & Leaf thickness $(\mathrm{mm})$ & Measurement of the thickness at the centre of each blade & Numerical \\
\hline & \multicolumn{3}{|l|}{ Vegetable production traits } \\
\hline 11. & Number of leaves per plant (no.) & The main countable leaves were counted along main stem & Numerical \\
\hline 12. & Total leaf area $\left(\mathrm{cm}^{2}\right)$ & $\begin{array}{l}\text { Data from number of leaves per plant were multiplied } \\
\text { with the average leaf area }\end{array}$ & Numerical \\
\hline \multicolumn{4}{|c|}{$\begin{array}{l}1=\text { erect or horizontally drooping at approximately } 1-10^{\circ}, 2=\text { semi-erect or horizontally drooping at approximately } 11-20^{\circ} \text {, } \\
3=\text { semi-erect or horizontally drooping at approximately } 21-30^{\circ}, 4=\text { horizontally drooping at approximately } 31-40^{\circ} \text {, } \\
5=\text { horizontally drooping at approximately } 41-50^{\circ}, 6=\text { horizontally drooping at approximately } 51-60^{\circ}, 7=\text { horizontally } \\
\text { drooping at approximately } 61-70^{\circ}, 8=\text { horizontally drooping at approximately } 71-80^{\circ} \text {, and } 9=\text { prostrate or horizontally drooping } \\
\text { at approximately } 81-90^{\circ}\end{array}$} \\
\hline \multicolumn{4}{|c|}{ b $1=$ elliptic, $2=$ ovate, $3=$ lanceolate, $4=$ obovate, $5=$ cordate, $6=$ obtuse, $7=$ aristate, $8=$ linear, $9=$ not known } \\
\hline
\end{tabular}


nitrogen and then freeze-dried (FD-1, EYELA, Rikakikai Co., Ltd., Tokyo, Japan). Samples (dry weight, $1 \mathrm{mg}$ ) were analyzed in duplicates.

\section{Data analysis}

Data distribution of morphological traits was plotted using Sigma Plot version 10. All statistical analyses (ANOVA, $t$ test, $F$ test, and correlation and cluster analysis) were performed using the JMP version 7.0 (SAS Institute, Cary, NC, USA). Based on the field observation, the phenotypic performance was varied among the two groups (Indonesian and worldwide accession). Therefore, the $t$ test was used to compare mean values, and the $F$ test was used to compare the variances between the two groups. Correlation analysis was performed to elucidate the relationships among the investigated traits. Cluster analyses using Ward's method was employed to group the 53 Indonesian accessions and to bring out the patterns of similarity and dissimilarity based on 10 morphological characters. By applying the cluster methods, selection of parental lines with desirable traits would be achieved. Two-dimensional scatter plots were used to assess the relationship between protein content and selected vegetable traits such as number of leaves, total leaf area and leaf thickness.

\section{Results}

Morphological traits and protein content

The variation in morphological traits and leaf protein content in Indonesian and worldwide amaranths were presented in Fig. 2. The morphological traits were grouped into four categories: (1) qualitative (Fig. 2a-c), (2) plant architecture (Fig. 2d-g), (3) leaf character (Fig. $2 \mathrm{~h}-\mathrm{j}$ ), and vegetable production traits (Fig. $2 \mathrm{k}-\mathrm{l}$ ).

\section{Qualitative traits}

Most of the Indonesian accessions (83\%) possessed upright stature and the rest were prostrate $(9 \%)$ and semi-erect (6\%), whereas in the worldwide accessions, $87 \%$ were upright and the rest were horizontally drooping with various deflection angles $(10 \%)$ and prostrate (3\%) (Fig. 2a). The predominant leaf shape in the Indonesian accessions was ovate $(81 \%)$, whereas other leaf shapes observed were elliptic (9\%), aristate $(6 \%)$, and lanceolate $(4 \%)$. In the worldwide accessions, a majority of the leaves were ovate $(65 \%)$, whereas the rest were elliptic (10\%), lanceolate (10\%), aristate $(7 \%)$, obovate (3\%), or obtuse (3\%) (Fig. 2b). Both groups showed high variability in leaf color, with green as the predominant $(70 \%)$ color. In the Indonesian group, other leaf colors included red-purple $(15 \%)$, green-variegated red or vice versa $(9 \%)$, and very dark green $(8 \%)$. In the worldwide accessions, the other leaf colors observed were green-variegated red or vice versa (13\%), red-purple (13\%), and red-purplevariegated green (3\%) (Fig. 2c).

Plant architecture traits

No statistically significant differences in terms of plant height and number of branches and internodes were observed between the Indonesian and worldwide groups (Figs. 2d-f). C. argentea (accession number or abbreviated as acc. nr. 24) was the shortest among all types but it had the highest number of branches and internodes. The second highest number of branches and internodes with an intermediate height were exhibited by $A$. hybridus (acc. nr. 81 and 84). Most of vegetable amaranths particularly those of $A$. tricolor L. had less branches and internodes, as shown by the Acehnese vegetable-type (acc. nr. 66).

A higher degree of variation in stem diameter was observed in the Indonesian accessions than in the worldwide accessions (Fig. 2g). Significant differences in the mean values and variations were also observed between the two groups. Within the Indonesian group, a large variation of stem diameter was observed, ranging from the thinnest to the thickest stems. Both were shown in A. dubius; namely acc. nr. 52 and acc. nr. 47, respectively.

\section{Leaf character traits}

No statistically significant differences were observed in the mean leaf area between the Indonesian and the worldwide groups (Fig. 2h). In contrast, leaf area varied significantly between the two groups; this might be attributed to the large differences in leaf area among the grain amaranths and other amaranth-types. A. cruentus L. (acc. nr. 13) exhibited the largest leaf area $\left(94 \mathrm{~cm}^{2}\right)$, followed by A. caudatus L. (acc. nr. 60), which is actually classified as grain species but in 

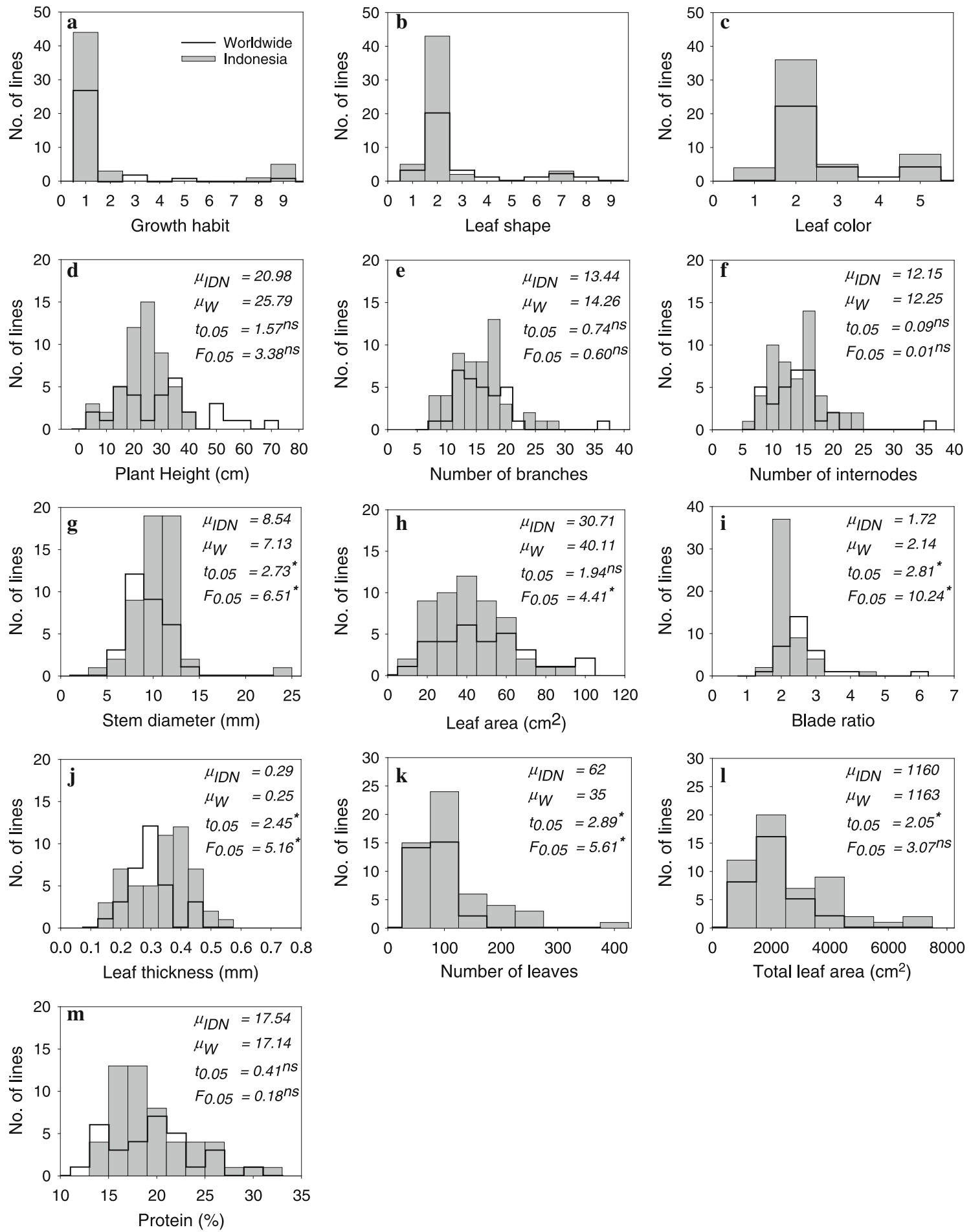

IDN = Indonesia $; \mathrm{W}=$ Worldwide

Fig. 2 Distribution of morphological traits in Amaranthus. Data for the worldwide $(\mathrm{N}=31)$ and Indonesian $(\mathrm{N}=53)$ collections are shown as black line and grey shaded bars, respectively 
Indonesia, it is utilized as a vegetable. A large variability in leaf area was found within the Indonesian group. The range of the variation was between $5 \mathrm{~cm}^{2}$ to almost $70 \mathrm{~cm}^{2}$ which were exhibited by A. hybridus (acc. nr. 83) and A. dubius (acc. nr. 33), respectively.

Blade ratio, which is useful in determining the form of a leaf, showed significantly higher variation in mean values in the worldwide collection than in the Indonesian collection (Fig. 2i). On the basis of our results, the blade ratios of the weedy and vegetable-types were typically between 1.5 and 2.0. The highest blade ratio (5.5) was observed in A. cruentus L. (acc. nr. 10) belongs to the grain species, whereas the lowest (1.2) was observed in A. tricolor L. (acc. nr. 23 and 78).

The Indonesian accessions showed significantly thicker leaves and higher variation than the worldwide collection (Fig. 2j). Our results implied that the most consumed Indonesian vegetable-types exhibited by A. tricolor L. (mean $=0.4 \mathrm{~mm}$ ) were 21 and $40 \%$ thicker than the average Indonesian and worldwide accessions, respectively. The Indonesian weedy-types showed higher variability in terms of leaf thickness $(0.1-0.5 \mathrm{~mm})$ and were approximately $30 \%$ thinner than the most commonly consumed vegetable-types in Indonesia.

\section{Vegetable production traits}

The mean value and variation in the number of leaves among Indonesian amaranths were significantly higher than those in the worldwide amaranths (Fig. 2k). Most of A. dubius collected from the highland areas of Takengon in Sumatra such as acc. nr. 34, exhibited extraordinarily higher numbers of leaves than the cultivated types (A. tricolor L.). In regard to this trait, Celosia spp. showed the lowest number of leaves among all types of amaranths. The mean total leaf area of the Indonesian and worldwide accessions were significantly different (Fig. 21). However, variation in the total leaf area did not differ significantly between the Indonesian and worldwide groups.

\section{Protein content}

The Indonesian and worldwide amaranth accessions did not show any significant differences in terms of leaf protein content (Fig. 2m). Most of weedy-types such as A. dubius generally showed the highest average protein content $(20 \%)$, whereas Celosia spp. showed $17 \%$ protein content. The cultivated species such as $A$. cruentus L. and A. tricolor L. exhibited an average protein content of $16 \%$.

Cluster analyses of morphological variation in Indonesian amaranths

The results of clustering (Fig. 3) revealed that the 53 Indonesian amaranth accessions could be broadly classified into four major groups at a distance scale of 9.5. The mean values of the morphological traits from each cluster are presented in Table 3.

Weedy-types were the most dispersed in each cluster. Cluster 1 consisted of 13 accessions, including 4 Celosia spp. and 8 weedy types such as A. blitum L., A. dubius, A. hybridus, A spinosus, A. viridis. The plants were characterized with low plant height, few leaves, and low total leaf area but showed high leaf blade ratio and protein content (Table 3). One A. tricolor L. (acc. nr. 80) was also included in Cluster 1 on the basis of characteristics that were similar to those of other weedy-types.

Seven weedy-types consisting of five A. dubius and two A. spinosus plants were distinctly grouped as Cluster 2. The morphological characteristics of the two A. spinosus plants closely resembled those of A. dubius during its early stages; however, axillary spines appeared at a later stage in A. spinosus. All weedy plants in Cluster 2 have originated from the highland areas of Takengon in Sumatra, and thus their morphology were similar to the highland adapted plants' features (e.g., tall plant with tender, small, and numerous leaves; highest number of branches; and large total leaf area) and notably high protein content (Table 3 ).

Cluster 3 comprised a mixture of weedy- (11 accessions); mostly represented by $A$. dubius and vegetable-types of A. tricolor L. and A. caudatus (4 accessions). These plants showed remarkably distinct morphotypes, such as the largest leaf area and the highest total leaf area, highest number of branches, and very thick leaves, but average protein content. Moreover, the weedy-types in cluster 3 showed phenotypes closely resembling the vegetable-types, except for A. spinosus (acc. nr. 36).

All vegetable accessions (A. tricolor L.) were distinctly grouped in Cluster 4. Only one weedy-type of A. dubius. (acc. nr. 47) was included in this cluster because of its shared morphological traits with common characteristics of vegetable plants, such as having 
Fig. 3 Dendrogram of Indonesian amaranths $(\mathrm{N}=53)$ on the basis of 10 morphological characteristics, constructed using Ward's method. The origin of each amaranth is enclosed within parentheses; the number after the slash indicates the accession number. $O R$ ornamental, $V G$ vegetable, and $W D$ weedy-type
Cluster 1

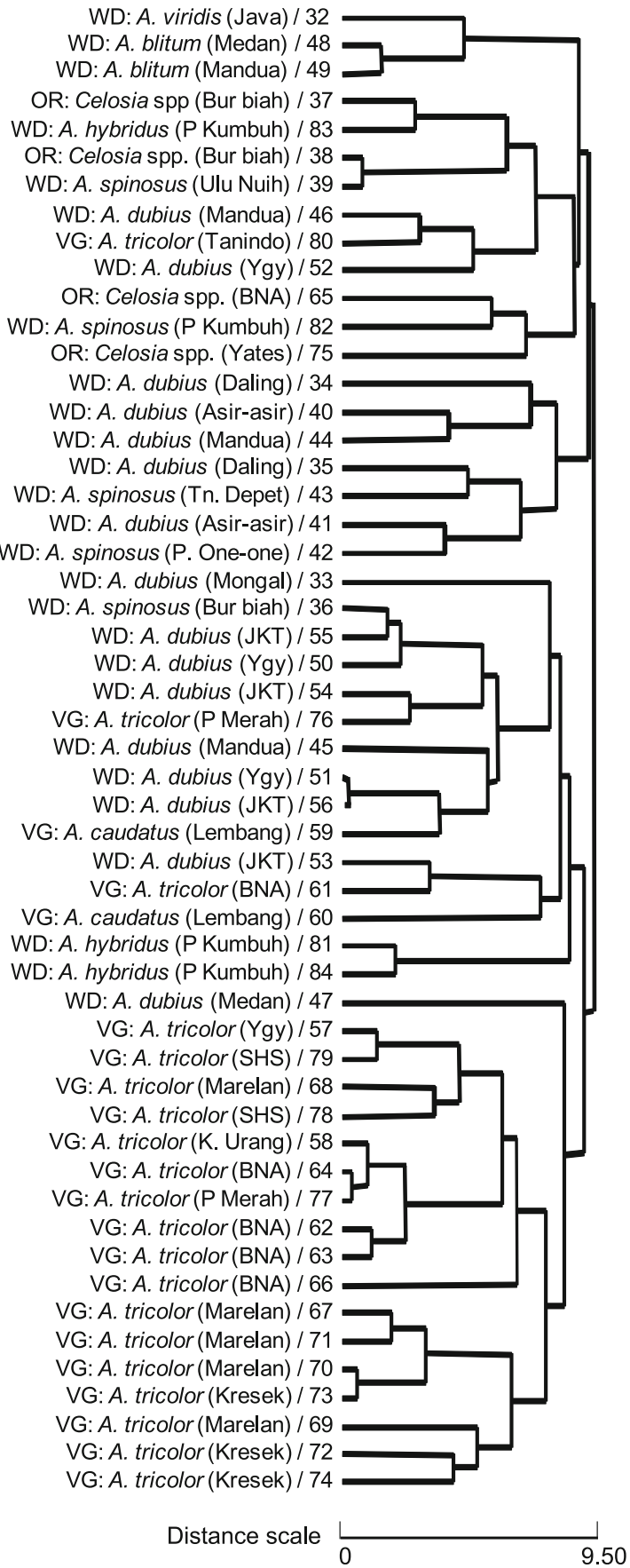

Correlations among morphological and protein traits

Total leaf area was shown to have a positive correlation with number of leaves and leaf area, stem diameter, number of branches and internodes (Table 4). The strongest correlation was observed a blade ratio of 1.5 and a very thick stem. The main phenotypes of cluster 4 were noted with thick stem and leaves, few leaves and branches, an average total leaf area, low protein content but an optimum blade ratio (1.5). The concerns about low content of protein and leaf number in the Indonesian vegetable-types were affirmed using these results. 
Table 3 Mean values of each morphological trait and protein content in the 4 clusters

\begin{tabular}{lllllllllll}
\hline Cluster & \multicolumn{1}{l}{ Morphological traits } \\
\cline { 2 - 10 } & H (cm) & SDM (mm) & NBR (no.) & NIN (no.) & NLV (no.) & LAR (cm $\left.{ }^{2}\right)$ & TLA (cm $\left.{ }^{2}\right)$ & RLW & LTK (mm) & PRT (\%) \\
\hline 1 & $13.75^{\mathrm{b}}$ & $6.14^{\mathrm{b}}$ & $13.16^{\mathrm{a}}$ & $11.27^{\mathrm{b}}$ & $33.93^{\mathrm{bc}}$ & $17.16^{\mathrm{c}}$ & $525.36^{\mathrm{b}}$ & $2.07^{\mathrm{a}}$ & $0.25^{\mathrm{b}}$ & $18.44^{\mathrm{ab}}$ \\
2 & $28.02^{\mathrm{a}}$ & $7.87^{\mathrm{ab}}$ & $16.91^{\mathrm{a}}$ & $16.16^{\mathrm{a}}$ & $188.38^{\mathrm{a}}$ & $13.21^{\mathrm{c}}$ & $2,552.61^{\mathrm{a}}$ & $1.75^{\mathrm{ab}}$ & $0.14^{\mathrm{c}}$ & $20.85^{\mathrm{a}}$ \\
3 & $20.59^{\mathrm{ab}}$ & $8.94^{\mathrm{a}}$ & $16.43^{\mathrm{a}}$ & $15.11^{\mathrm{a}}$ & $67.93^{\mathrm{b}}$ & $46.37^{\mathrm{a}}$ & $2,987.37^{\mathrm{a}}$ & $1.64^{\mathrm{b}}$ & $0.35^{\mathrm{a}}$ & $17.28^{\mathrm{ab}}$ \\
4 & $23.78^{\mathrm{a}}$ & $10.22^{\mathrm{a}}$ & $9.80^{\mathrm{b}}$ & $8.76^{\mathrm{b}}$ & $29.55^{\mathrm{c}}$ & $34.25^{\mathrm{b}}$ & $1,027.64^{\mathrm{b}}$ & $1.52^{\mathrm{b}}$ & $0.33^{\mathrm{a}}$ & $15.81^{\mathrm{b}}$ \\
\hline
\end{tabular}

Same alphabets show no statistical difference (Tukey-Kramer test; $p<0.05$ )

$H$ plant height, SDM stem diameter, NBR number of branches, NIN number of internodes, $N L V$ number of leaves, $L A R$ leaf area, TLA total leaf area, $R L W$ blade ratio, $L T K$ leaf thickness, $P R T$ protein

Table 4 Correlation matrices for the morphological traits and protein contents in the amaranths $(\mathrm{N}=84)$

\begin{tabular}{|c|c|c|c|c|c|c|c|c|c|c|}
\hline Number & Traits & (2) & (3) & (4) & (5) & (6) & (7) & (8) & (9) & (10) \\
\hline (1) & Plant height $(\mathrm{cm})$ & 0.175 & 0.172 & $0.258^{*}$ & 0.196 & 0.073 & 0.112 & -0.052 & 0.104 & -0.192 \\
\hline (2) & Stem diameter $(\mathrm{mm})$ & - & 0.085 & 0.045 & 0.030 & $0.364 * *$ & $0.279 *$ & $-0.267^{*}$ & $0.333^{*}$ & -0.114 \\
\hline (3) & $\begin{array}{l}\text { Number of branches } \\
\text { (unit) }\end{array}$ & & - & $0.939 * *$ & $0.336 * *$ & 0.168 & $0.366 * *$ & 0.204 & -0.184 & -0.164 \\
\hline (4) & $\begin{array}{l}\text { Number of internodes } \\
\text { (unit) }\end{array}$ & & & - & $0.417 * *$ & 0.052 & $0.393 * *$ & 0.146 & -0.185 & -0.175 \\
\hline (5) & Number of leaves (unit) & & & & - & $-0.299 *$ & $0.607 * *$ & -0.122 & $-0.321 *$ & $0.263^{*}$ \\
\hline (6) & Leaf area $\left(\mathrm{cm}^{2}\right)$ & & & & & - & $0.357 * *$ & -0.065 & $0.446 * *$ & -0.082 \\
\hline (7) & Total leaf area $\left(\mathrm{cm}^{2}\right)$ & & & & & & - & -0.208 & 0.088 & 0.129 \\
\hline (8) & Blade ratio & & & & & & & - & -0.048 & -0.064 \\
\hline (9) & Leaf thickness (mm) & & & & & & & & - & $-0.221 * *$ \\
\hline (10) & Protein $(\%)$ & & & & & & & & & - \\
\hline
\end{tabular}

$*$ and ** represent significance at $P<0.05$ and $P<0.01$, respectively

with number of leaves. Leaf number was shown to have a negative correlation with leaf area and thickness, indicating that the more leaves amaranths produced, the smaller and thinner the leaves were. No significant correlations were shown between blade ratio and any morphological trait, except for stem diameter. The height of the amaranths showed no correlation with stem diameter or number of leaves and branches, but taller amaranths significantly showed more internodes. Protein content showed a significant correlation with leaf number and thickness.

Relationship between protein content and selected vegetable traits

The relationship between protein content and selected vegetable traits such as number of leaves, total leaf area and leaf thickness were investigated (Fig. 4). Three A. dubius accessions (acc. nr. 40, 41, and 44) showed remarkably high leaf numbers and protein content (Fig. 4a). Extraordinarily high protein content, albeit small to intermediate total leaf area, was identified in acc. nr. 4 (A. blitum L.), acc. nr. 32 (A. viridis), and acc. nr. 33 (A. dubius). In contrast, A. dubius (acc. nr. 34, 53) and A. tricolor L. (acc. nr. 61) showed remarkably large total leaf areas but very variable protein content (Fig. 4b). The relationship between protein content and leaf thickness is shown as a scatter plot diagram in Fig. 4c. The highest variation in protein content was observed in the amaranths with leaf thickness ranging from 0.15 to $0.30 \mathrm{~mm}$, which was commonly observed in the weedy-types. In terms of the relationship between protein content and leaf thickness, the main Indonesian commercial vegetable amaranths mostly represented by $A$. tricolor L. showed variation in leaf thickness ranging from 0.31 to $0.50 \mathrm{~mm}$ but low to average protein content. These results validated the observations previously presented in Fig. $2 \mathrm{j}$. 

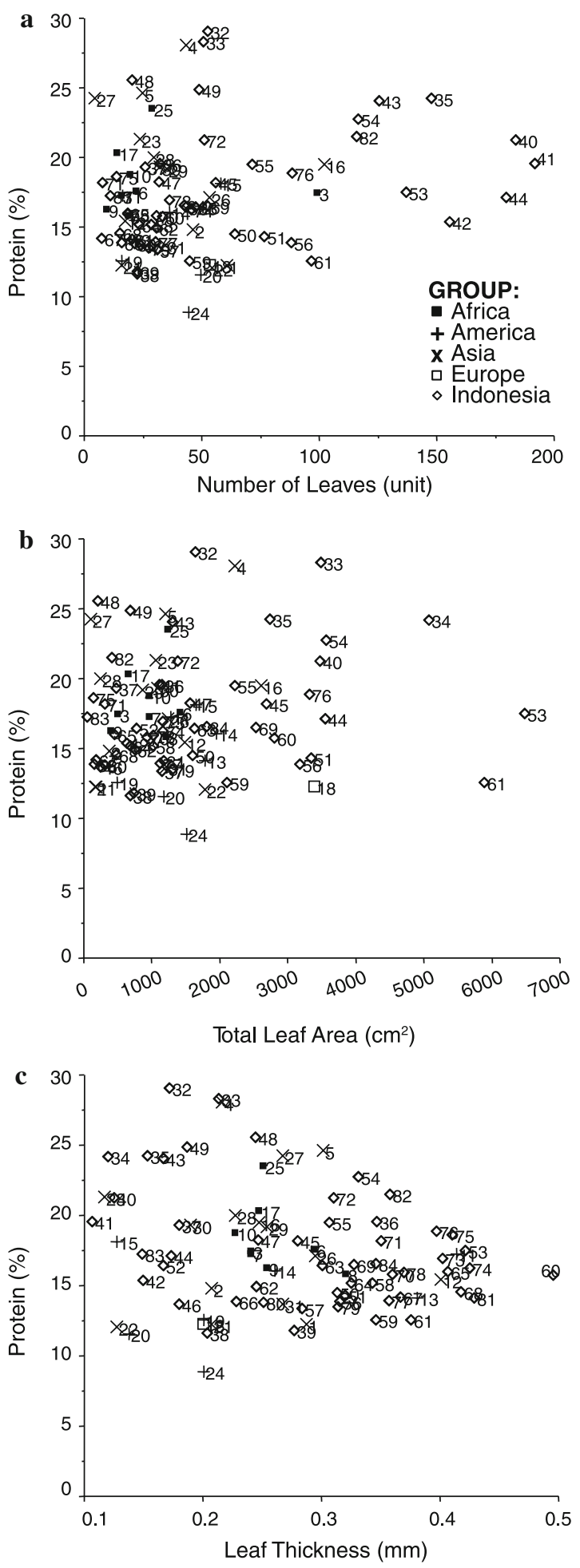

Fig. 4 The relationship of protein content to leaf number (a), total leaf area (b), and leaf thickness (c). Numbers correspond to amaranth accession numbers (see Table 1)

\section{Discussion}

The availability of genetic resources and their diversity assessment is a point for the success of breeding programs for any crop, including amaranths (Hoisington et al. 1999). Germplasm collections from underutilized crops can become essential resources for plant breeders to develop improved cultivars that will feed rapidly growing populations (Nelson 2011). Attempts have been made to use exotic germplasms obtained from weedy or wild relatives for crop improvement via gene introgression, cultivar selection, and conventional breeding (Hajjar 2005; Sagnard et al. 2011). To date, the genetic resources of Indonesian amaranths remain unexplored. Their screening at the morphological level will serve as an initial attempt to facilitate improvement of vegetable amaranths.

As there has been no available references, we have tried to measure the variation of Indonesian amaranths based on their phenotypic performance and then to compare them with the worldwide variation. In this study, the worldwide variation served as a preliminary reference which enabled us to value the potential of Indonesian resources for further breeding efforts. Based on our results, the average values and variations in most morphological traits and protein content in the Indonesian accessions were shown to be generally similar to those of the worldwide ones. Nevertheless, higher variation in the morphological appearance noted with higher standard deviation was shown by the Indonesian amaranths, especially in terms of stem diameter, leaf number and thickness in the weedy types. This finding is according to Pickersgill (1981) who stated that higher level of variability in morphological traits is maintained in many of weedy or wild relatives of the crops. Furthermore, higher variation in the morphological appearance might indicate higher variability at the genetic level (Jain et al. 1980). The higher variation in the morphological appearance observed in Indonesian amaranth accessions might be explained in three possible ways: (1) lack of selection pressure due to artificial or domestication processes (Chan and Sun 1997), as the variations have existed naturally and breeding-efforts have not yet been initiated in Indonesian amaranths; (2) mixedmating system of amaranths may facilitate the natural introgression process (Kulakow and Hauptli 1994). Although self pollination is more likely to occur, amaranths may have combined their natural ability of 
self and cross pollination through wind, with mean outcrossing rates ranging from 4 to $34 \%$ (Brenner and Widrlechner 1998; Kulakow and Hauptli 1994). Frequent outcrossing might have resulted in large numbers of varieties and a wide range of morphological diversity in amaranths (Das 2011). Natural introgression was also observed in other diverse plant species (Jarvis and Hodgkin 1999). However, Pal and Khoshoo (1972) argued that interspecific hybrids or natural introgression might not occur easily in amaranths due to the sterility and viability problems in the $\mathrm{F}_{1}$ seeds. Our data were consistent with the view that natural introgression among cultivated vegetables and weedy amaranths might have occurred in Indonesia, as shown by Cluster 3. In our work, cluster analysis was shown to be a helpful tool to group the Indonesian amaranths' resources based on the similarity of the ten morphological characteristics. Hence, the usefulness of cluster analysis in grouping germplasm collection based on similar morphological variations has been demonstrated in many crop plants, such as in sorghum (Ayana and Bekele 1999) and rice (Arietta-Espinoza et al. 2005). Such classification is simple, reliable and helpful to elucidate the distinct patterns of variation and evolutionary history; (3) Polyploidy, leading to gene combination, might have resulted in higher morphological variation. Most of the weedy-types assessed in our Indonesian accessions were A. dubius, which is the only known natural tetraploid amaranth species (Grubben 2004). Furthermore, they usually develop distinct morphological characters and undergo vigorous growth ( $\mathrm{Pal}$ 1972). The above average performance of $A$. dubius was confirmed by our results. Further studies at the molecular level would be required to validate the occurrence of introgression and polyploidy in Indonesian amaranths.

Weedy resources are considered as rich sources of variation, and act as a reservoir of genetic diversity. Their assessment plays a vital role in crop improvement (Pickersgill 1981). Our study of Indonesian weedy amaranths also supports this notion. Moreover, this study has shown several morphological traits, such as leaf number and area, stem diameter, number of branches and internodes (except the height of the plant) that might influence the total leaf area, which is considered as an indirect parameter of yield in amaranths. Previously, Shukla et al. (2006) reported the positive contribution of several morphological (including stem diameter and leaf area) and nutritional quality traits to the foliage yield in vegetable amaranths (A. tricolor L.). Furthermore, those two traits showed relatively high heritability values $\left(\mathrm{h}^{2}>0.95\right)$, but Shukla et al. (2006) proposed that non-additive gene action might play a vital role in the transmission of these characters to the offspring.

A negative correlation between number of leaves and leaf area $\left(\mathrm{r}=-0.3^{*}\right)$ might act as a challenge in the improvement of yield in amaranths. Breeding strategies should focus on increasing the area of each individual leaf or on producing more leaves in each main branch. Indonesian weedy resources might potentially serve as parental lines, particularly A. dubius accessions originating from the highlands of Takengon (acc. nr. 40, 41, and 44) that show a remarkably high number of leaves. In terms of improving the quality of vegetable amaranths, the results of this study suggest that leaf thickness is considered as a quality parameter, as acknowledged by the Asian Vegetable Research Development Centre (Acedo 2010). Leaf thickness plays a key role in palatability and is directly related to consumer acceptance. In general, Indonesian consumers prefer tender, thin, and middle-sized leaves with a blade ratio of 1.5-2.0 (personal observation and farmers' interview). Exclusively, the chip industries of fried amaranth's leaves in Western Java prefer thick leaves with large leaf areas and high blade ratios. For leaf quality improvement, Indonesian accessions of A. dubius (e.g., acc. nr. 33) may be selected as parental lines. If those positive characteristics from selected parental lines can be transferred via interspecific crossing, then new varieties with improved performance and desired traits can be developed. Interspecific crossing to produce hybrids in Amaranthus is possible to be obtained. However, this would not be so easily achieved due to reproductive barriers such as male sterility in the pollen grains (Gudu and Gupta 1988) and low pollen fertility (Gupta and Gudu 1991). Thus, both factors has made the production of $F_{1}$ seeds difficult to be obtained. Moreover, the chromosome number difference of $A$. dubius $(\mathrm{n}=32)$ as the only known tetraploid species with the rest of Amaranthus' species ( $n=16$ or 17 ), were believed to be the main barrier in the gene exchange between the weedy and the cultivated amaranths (Greizerstein and Poggio 1995; Pandey 1999). Therefore, conventional breeding such as backcrosses (Coons 1982) or modern breeding technologies via cytoplasmic male sterility 
(Sodhi et al. 2006) may help us to overcome such constraints.

Leaf protein content and nutritional value, including that of carotenoids and minerals, are considered as the most important quality parameters in vegetables, particularly in amaranths (Shukla et al. 2010). Our result reaffirmed the nutritional potential of underutilized crops such as amaranths and Celosia. The high protein content in Celosia-leaves as compared to that in the common vegetable amaranths (A. tricolor L.), should be considered as an alternative crop to augment malnutrition, especially in tropic and famished regions worldwide (National Academy of Sciences 2006).

The observed similarity in the levels of variation in protein content among the Indonesian and worldwide amaranth accessions serves as an opportunity for breeders to increase protein content in Indonesian vegetable-types, especially those in Cluster 4. Cluster and scatter plot analyses have enabled us to identify specific weedy accessions that show potential for increase in protein content. It was mentioned in the sect. "Introduction" that A. blitum L. was found to be high in its protein content. Based on the result of this study, other weedy species such as $A$. viridis and A. dubius (acc. nr. 32, 33 and 34 grouped in Clusters 1, 2 and 3) were found to be good resources for the improvement of leaf protein content and total leaf area. By combining the superior nutritional characteristics of weedy-types with the good external appearance of vegetable amaranths via genetic recombination and selection, new vegetable varieties with high protein content can be obtained by breeding weedy types with superior nutritional characteristics with vegetable types producing better biomass. This will remain as the plant breeder's task of transferring the useful trait from weedy to cultivated amaranth without adversely affecting other economically important traits.

\section{Conclusions}

In this study, the Indonesian amaranth accessions were revealed to have high levels of genetic variability, with most morphological traits and protein content levels similar and in some cases, superior to those of the worldwide germplasm. The superior traits include leaf number, stem diameter, and leaf thickness-features that are essential parameters in vegetable improvement. Cluster and scatter plot analyses identified potential candidates for vegetable breeding programs.
Indonesian A. viridis (accession number 32) and A. dubius (accession numbers 33, 34, 41, and 44) accessions could serve as valuable parental lines for the improvement of protein content and yield, respectively. The relatively high protein content in Celosia leaves could potentially make this plant an alternative protein-rich vegetable.

Acknowledgments We gratefully acknowledge Dr. David Brenner (USDA-NPGS, Iowa State University) for providing comments regarding our manuscript and contributing the seeds of the worldwide accessions used in this research. We are grateful to Dr. Brigitte L. Maass (International Center for Tropical Agriculture, Kenya) for comments on the manuscript. Finally, we express our sincerest gratitude to the farmers in Sumatra and Java, who provided seeds and participated in the interviews, freely providing germplasm and information essential for the study.

Open Access This article is distributed under the terms of the Creative Commons Attribution License which permits any use, distribution, and reproduction in any medium, provided the original author(s) and the source are credited.

\section{References}

Acedo AL Jr. (2010) Post harvest technology for leafy vegetables. AVRDC-ADB Postharvest projects RETA 6208/ 6376. AVRDC Publication No. 10-733. AVRDC-the world vegetable centre, Taiwan, pp 2-5

AOAC (1980) Kjeldahl method for nitrate containing samplesofficial final action. In: Horwitz W (ed) Official methods of analysis of the Association of Official Analytical Chemists. Published by the Association of Official Analytical Chemists PO BOX 540, Benjamin Franklin Station, 20044 Washington, DC, p 15

Arietta-Espinoza G, Sánchez E, Vargas S, Lobo J, Queasada T, Espinoza AM (2005) The weedy rice complex in Costa Rica. I. Morphological study of relationships between commercial rice varieties, wild Oryza relatives and weedy types. Genet Resour Crop Evol 52:575-587

Ayana A, Bekele E (1999) Multivariate analysis of morphological variation in sorghum (Sorghum bicolor (L.) Moench) germplasm from Ethiopia and Eritria. Genet Resour Crop Evol 46:273-284

Brenner DM (2002) Amaranth descriptor, USDA. Descriptor site (s):NC7. http://www.ars-grin.gov/npgs/descriptors/amaranth, pp 1-13. Accessed autumn 2009

Brenner DM, Widrlechner MP (1998) Amaranthus seed regeneration in plastic tents in green houses. Plant Genet Resour Newsl 116:1-4

Brenner DM, Baltensperger DD, Kulakow PA, Lehmann JW, Myers RL, Slabbert MM, Sleugh BB (2000) Genetic resources and breeding of Amaranthus. In: Janick J (ed) Plant breeding reviews, vol 19. Wiley, USA, pp 227-285

Chan KF, Sun M (1997) Genetic diversity and relationships detected by isozyme and RAPD analysis of crop and wild species of Amaranthus. Theor Appl Genet 95:865-873 
Coons MP (1982) Relationships of Amaranthus caudatus. Econ Bot 36(2):129-146

Costea M, Tardif FJ, Brenner DM (2003) Notes on economic plants. Econ Bot 57(4):646-649

Das S (2011) Systematics and taxonomic delimitation of vegetable, grain and weed amaranths: a morphological and biochemical approach. Genet Resour Crop Evol 59:289-303

Denton OA (2004) Celosia argentea L. (Internet) Record from protabase. Grubben GJH, Denton OA (eds), PROTA (Plant Resources of Tropical Africa), Wageningen, Netherlands. https://database.prota.org/search.htm. Accessed 9 Apr 2012

Espitia-Rangel E (1994) Breeding of grain amaranth. In: Paredes-López O (ed) Amaranth: biology, chemistry, and technology. CRC Press, Boca Raton, pp 23-38

Greizerstein EJ, Poggio L (1995) Meiotic studies of spontaneous hybrids of Amaranthus: genome analysis. Plant Breeding 114:448-450

Grubben GJH (1976) The cultivation of Amaranth as a tropical leaf vegetable with special reference to South Dahomey. Department of Agricultural Research of the Royal Tropical Institute Amsterdam, pp 1-207

Grubben GJH (1994) Amaranthus L. In: Siemonsma JS, Piluek K (eds) Prosea: plant resources of South-East Asia 8. Vegetables. Prosea Foundation, Bogor, pp 82-86

Grubben GJH (2004) Amaranthus dubius Mart. ex Thell. (Internet) record from protabase. Grubben GJH, Denton OA (eds), PROTA (Plant Resources of Tropical Africa), Wageningen, Netherlands. https://database.prota.org/ search.htm. Accessed 9 Apr 2012

Gudu S, Gupta VK (1988) Male-sterility in the grain amaranth (Amaranthus hypochondriacus ex-Nepal) variety Jumla. Euphytica 37:23-26

Gupta VK, Gudu S (1991) Interspecific hybrids and possible phylogenetic relations in grain amaranths. Euphytica 52: $33-38$

Hadisoeganda RWW (1996) Amaranth: livelihood support for farmers in Indonesia (In Indonesian language). Indones Veg Res Inst Monogr 4:1-32

Hajjar R (2005) Wild relatives for better crop performance. Geneflow. IPGRI Newsletter, p 28

Hauptli H, Jain SB (1983) Genetic structure of landrace populations of the new world grain amaranths. Euphytica 33: 875-884

Hoisington D, Khairallah M, Reeves T, Ribaut JM, Skovmand B, Suketoshi T, Warburton M (1999) Plant genetic resources: what can they contribute toward increased crop productivity? Proc Natl Acad Sci 96:5937-5943

Jain SK, Wu L, Vaidya KR (1980) Levels of morphological and allozyme variation in Indian amaranths: a striking contrast. J Hered 71:283-285

Jarvis DI, Hodgkin T (1999) Wild relatives and crop cultivars: detecting natural introgression and farmer selection of new genetic combinations in agroecosystem. Mol Ecol 8:159-173

Kulakow PA, Hauptli H (1994) Genetic characterization of grain amaranth. In: Paredes-López O (ed) Amaranth: biology, chemistry, and technology. CRC Press, Boca Raton, pp 9-22

Maulana M, Sayaka B (2007) The features of vegetables in Indonesia and the current policy in the framework of agricultural development. Analisis Kebijakan Pertanian 5(3):267-284
National Academy of Sciences (2006) Lost crops of Africa, vol II: vegetables. The National Academic Press, Washington, D.C., pp 1-379

Nelson RL (2011) Managing self-pollinated germplasm collection to maximize utilization. Plant Genet Resour 9(1): 123-133

Olaniyi JO, Ojetayo AE (2012) Effects of nitrogen on growth, yield, and nutrient uptake and quality of celosia (Celosia argentea) varieties. J Agric Biol Sci 3(1):227-231

Pal M (1972) Evolution and improvement of cultivated amaranths. III. Amaranthus spinosus-dubius complex. Genetica 43:106-118

Pal M, Khoshoo TN (1972) Evolution and improvement of cultivated amaranths. J Hered 63(2):78-82

Pandey RM (1999) Evolution and improvement of cultivated amaranths with reference to genome relationship among A. cruentus, A. powellii and A. retroflexus. Genet Resour Crop Evol 46:219-224

Pickersgill B (1981) Biosystematic of crop-weed complexes. Kulturpflanze 29:377-388

Sagnard F, Deu M, Dembélé D, Leblois R, Touré L, Diakité M, Calatayud C, Vaksmann M, Bouchet S, Mallé Y, Togola S, Sibiry Traoré PC (2011) Genetic diversity, structure, gene flow and evolutionary relationships within the Sorghum bicolor wild-weedy-crop complex in a western African region. Theor Appl Genet. doi:10.1007/s0012201116620

Shukla S, Bhargava A, Chatterjee A, Srivastava A, Singh SP (2006) Genotypic variability in vegetable amaranth (Amaranthus tricolor L.) for foliage yield and its contributing traits over successive cuttings and years. Euphytica 151:103-110

Shukla S, Bhargava A, Chatterjee A, Pandey AC, Mishra BK (2010) Diversity in phenotypic and nutritional traits in vegetable amaranth (Amaranthus tricolor), a nutritionally underutilized crop. J Sci Food Agric 90:139-144

Sodhi YS, Chandra A, Verma JK, Arumugam N, Mukhopadhyay A, Gupta V, Pental D, Pradhan AK (2006) A new cytoplasmic male sterility system for hybrid seed production in Indian oilseed mustard Brassica juncea. Theor Appl Genet 114:93-99

USDA (2011) United States Department of AgricultureAgriculture Research Service (USDA-ARS), National Genetic Resources Program Germplasm Resources Information Network (GRIN). (Online Database) National Germplasm Resources Laboratory, Beltsville, Maryland. Available at: http://www.ars-grin.gov/npgs/. Accessed on 6 Dec 2011

Wargiono J, Richana N, Hidajat A (2002) Contribution of cassava leaves used as a vegetable to improved human nutrition in Indonesia, pp 466-471. http://webapp.ciat.cgiar. org/asia_cassava/pdf/proceedings_workshop_02/466.pdf. Accessed on 30 Nov 2011

Westphal E (1994) Ipomoea aquatica Forsskal. In: Siemonsma JS, Piluek K (eds) Prosea: plant resources of South-East Asia 8. Vegetables. Prosea Foundation, Bogor, pp 181-184

Wu H, Sun M, Yue S, Sun H, Yizhong C, Huang R, Brenner DM, Corke H (2000) Field evaluation of an Amaranthus genetic resource collection in China. Genet Resour Crop Evol 47:43-53 